\title{
Nitric oxide (NO) signalling in plant nanobiology: current status and perspectives
}

Zsuzsanna KOLBERT ${ }^{1 *}$ (kolzsu@bio.u-szeged.hu), Réka SZÖLLÖSI ${ }^{1}$ (szoszo@bio.uszeged.hu), Gábor FEIGL ${ }^{1}$ (feigl@ bio.u-szeged.hu), Zoltán KÓNYA² (konya@chem.uszeged.hu), Andrea RÓNAVÁRI² (ronavari@ chem.u-szeged.hu)

${ }^{1}$ Department of Plant Biology, Faculty of Science and Informatics, University of Szeged, H6726 Szeged, Közép fasor 52., Hungary

2 Department of Applied and Environmental Chemistry, Faculty of Science and Informatics, University of Szeged, H-6720 Szeged, Rerrich Bela ter 1., Hungary

*corresponding author email: kolzsu@bio.u-szeged.hu, +36-30-368-1102 


\section{Highlights}

Here we discuss the role of nitric oxide (NO) in plant responses to nanomaterials like chitosan nanoparticles (NPs), metal-oxide NPs, nanotubes and NO-releasing NPs providing new insights in plant naNObiology. 


\begin{abstract}
Plant nanobiology as a novel research field provides scientific basis for the agricultural use of nanoparticles (NPs). Plants respond to the presence of nanomaterials by synthesizing signal molecules, such as the multifunctional gaseous nitric oxide (NO). Several reports have described the effects of different nanomaterials (primarily chitosan NPs, metal oxide NPs and carbon nanotubes) on endogenous NO synthesis and signalling in different plant species. Other works have demonstrated the ameliorating effect of exogenous NO donor (primarily sodium nitroprusside) treatments on NP-induced stress. NO-releasing NPs are more preferred alternatives to chemical NO donors and evaluating their effects on plants has recently begun. The accumulated literature data clearly indicate that endogenous NO production in the presence of nanomaterials or NO levels increased by exogenous treatments (NO-releasing NPs or chemical NO donors) exerts growth-promoting and stress-ameliorating effects in plants. Furthermore, a NP-based nanosensor for NO detection in plants has been developed, providing a new and excellent perspective for basic research and also for the evaluation of plants' health status in agriculture.
\end{abstract}

Keywords: carbon nanotubes, chitosan nanoparticles, metal-oxide nanoparticles, nitric oxide-releasing nanoparticles, nitric oxide, nanobiology, nanosensor, plants 
Abbreviations: catalase, CAT; 2-(4-carboxyphenyl)-4,4,5,5-tetramethylimidazoline-1-oxyl3-oxide, cPTIO; carbon nanotubes, CNTs; chitosan nanoparticles, CNPs; glutathione, GSH; hydrogen peroxide, $\mathrm{H}_{2} \mathrm{O}_{2}$; multi-walled carbon nanotubes, MWCNTs; nitrate reductase, NR; nitric oxide, NO; peroxidase, POX; peroxynitrite, $\mathrm{ONOO}^{-}$; reactive oxygen species, ROS; single-walled carbon nanotubes, SWNTs; sodium nitroprusside, SNP; superoxide radical, $\mathrm{O}_{2}$; superoxide dismutase, SOD; S-nitroso-glutathione, GSNO; S-nitroso-mercaptosuccinic acid chitosan nanoparticles, S-nitroso-MSA-CS NPs; S-nitrosothiol, SNO. 


\section{Introduction}

Nanotechnology has been highlighted as a promising field of interdisciplinary research in the last decades. Its potential in developing sustainable agriculture is also getting attention nowadays. Indeed, agriculture practices can effectively be improved by the application of nanoparticles (NPs) as nanopesticides, nanoherbicides, nanofertilizers, nanosensors, and growth stimulants (Fraceto et al., 2016; Shang et al., 2019; Maksimović et al., 2019). NPs are organic or inorganic materials with 1-100 nm size at least in one dimension (Ellenbecker and Tsai, 2015), which can have both natural (e.g. volcanic activity) and anthropogenic sources. Man-made nanoparticles can be synthetized as a by-product of industrial activities or as a deliberate product with particular properties for a specific purpose. Based on the core material, NPs can be divided into inorganic and organic NPs. Inorganic NPs include metals (e.g. Al, Bi, $\mathrm{Co}, \mathrm{Cu}, \mathrm{Au}, \mathrm{Fe}, \mathrm{In}, \mathrm{Mo}, \mathrm{Ni}, \mathrm{Ag}, \mathrm{Sn}, \mathrm{Ti}, \mathrm{W}, \mathrm{Zn}$ ), metal oxides $\left(\mathrm{Al}_{2} \mathrm{O}_{3}, \mathrm{CeO}_{2}, \mathrm{CuO}, \mathrm{Cu}_{2} \mathrm{O}, \mathrm{In}_{2} \mathrm{O}_{3}, \mathrm{La}_{2} \mathrm{O}_{3}, \mathrm{MgO}, \mathrm{NiO}, \mathrm{TiO}_{2}, \mathrm{SnO}_{2}, \mathrm{ZnO}, \mathrm{ZrO}_{2}\right)$ and quantum dots. Organic NPs are liposomes, dendrimers, micelles, fullerenes, and carbon nanotubes (Khalid et al., 2020).

As for crop production, low NP doses exert direct positive effects on seed germination and vegetative and reproductive growth of plants, as was experimentally verified by several studies in species like rice, wheat, tobacco, coffee, soybean etc. (reviewed in detail by Shang et al., 2019). At the same time, NP may cause toxic symptoms (stunted root and shoot growth, chlorosis, necrosis) in plants, and the toxicity depends on several factors like chemical composition, chemical structure, size, surface area and concentration of nanoparticles, duration of exposure, plant species, developmental phase and treatment conditions (Ruttkay-Nedecky et al., 2017; Singh et al., 2018; Sturikova et al., 2018).

Plants come into contact with NPs via both their shoot and root system. Available literature indicates that NPs can internalize leaf tissues through e.g. stomata, trichomes or hydathodes and enter root tissues via rhizodermis and lateral root junctions or wounds (Schwab et al., 2016; Ruttkay-Nedecky et al., 2017). Regarding the mechanism of NP internalization, several mechanisms have been proposed such as endocytosis, pore formation, carrier protein- or plasmodesmata-mediated entry or snorkelling (Schwab et al., 2016). However, NP uptake into plant tissues depends on factors like particle size, chemical composition, or morphology (Pérez-de-Luque, 2017). Beyond direct NP uptake, ion release is a further scenario for the interaction between metal NPs, metal oxide NPs and plants (Pérezde-Luque, 2017). 
Plants respond to environmental cues such as the presence of NPs by the synthesis of signal molecules. Among gaseous signal molecules (e.g. hydrogen sulphide, ethylene, carbon monoxide), nitric oxide (NO), having been extensively studied in the last forty years, has a prominent role (Kolbert et al., 2019). Its small size, redox properties and hydrophobic character allow its effective participation in the regulation of plant growth and development, as well as in stress responses. Nitric oxide present in the atmosphere and formed in the soil during nitrification and denitrification can be taken up by plants, but plants themselves produce NO using several oxidative and reductive metabolic pathways.

In living organisms, endogenous NO synthesis may occur uniformly by the oxidation of reduced $\mathrm{N}$ compounds such as L-arginine, polyamines or hydroxylamine. Yet the synthesis of NO in higher plants is special, since it differs from all other living organisms (even from algae). In higher plants, L-arginine may be converted by the activity of a mammalian nitric oxide synthase- (NOS)- like enzyme or enzyme complex that has not been identified so far (Gupta et al., 2019). Oxidative degradation of polyamines can directly or indirectly result in the formation of NO, but the exact mechanism has not yet been elucidated (Wimalasekera $e t$ al., 2011), similarly to the process of NO release from hydroxylamine and salicylhydroxamate (Rümer et al., 2009). Additionally, NO is formed by the reduction of oxidized $\mathrm{N}$ compounds such as nitrate and nitrite, therefore it is connected to nitrate assimilation (Sanz-Luque et al., 2013). Earlier studies reported that NO production is associated with nitrate reductase (NR) activity in various plant tissues and diverse growth conditions (Hao et al., 2010; Mur et al., 2013; Lu et al., 2014; Medina-Andres et al., 2015). Recent evidences in Chlamydomonas indicate, however, that NR plays an indirect role in NO synthesis by providing electron source for the NO-forming nitrite reductase (NOFNiR), which might be a relevant mechanism also in higher plants (Chamizo-Ampudia et al., 2016; 2017). Beyond NR, the activity of the root-cell-specific nitrite:NO reductase (NiNOR, Stöhr et al., 2001) catalyses nitrite reduction-associated NO formation. Furthermore, NO and ATP formation via cytochrome c oxidase and/or reductase and possibly by alternative oxidase at the mitochondrial inner membrane was suggested (Stoimenova et al., 2007). Non-enzymatic processes like spontaneous nitrite reduction at acidic $\mathrm{pH}$ in the presence of ascorbate in cell walls can also be considered (Bethke et al., 2004).

Diverse reactions of NO in biological systems ensure its removal and the precise control of its steady-state level. Interactions of NO with molecular oxygen yield nitrite and nitrate, and the NO-phytoglobin reaction leads to the formation of nitrate (Perazzolli et al., 
2004; Hebelstrup et al., 2006). The conversion of NO into nitrate is also possible due to the activity of truncated haemoglobin THB1 receiving electron from NR (Sanz-Luque et al., 2013; Chamizo-Ampudia et al., 2017). Furthermore, the formation of S-nitrosothiols (SNO) such as S-nitrosocysteine (CysNO) or S-nitrosoglutathione (GSNO) in the reaction between NO and thiol- (SH)-containing proteins and peptides may influence steady-state NO levels, since SNOs are capable of NO liberation (Hogg, 2000; Stamler et al., 2001; Foster et al., 2003). The most abundant SNO is GSNO, which can non-enzymatically liberate NO or be reduced by the enzyme $S$-nitrosoglutathione reductase (GSNOR), yielding oxidized glutathione (GSSG) and ammonia $\left(\mathrm{NH}_{3}\right)$ resulting in $\mathrm{NO}$ removal (Barroso et al., 2006; Corpas et al., 2008b; Leterrier et al., 2011). Due to its stable character, GSNO may serve as a long-distance transport form of NO signal (Lindermayr, 2018; Begara-Morales et al., 2018). SNOs exert relevant biological functions such as transnitrosation of target proteins, by which NO signal perception is partly realized. The reversible reaction between GSNO and protein cysteine thiols leads to modifications in protein structure and activity and consequently in signal transduction. Reaction of $\mathrm{NO}$ with superoxide radical $\left(\mathrm{O}_{2}{ }^{-{ }^{-}}\right)$produces peroxynitrite (ONOO-, Beckman et al., 1990), which may be in turn scavenged by flavonoids, ascorbic acid, gamma tocopherols and enzymes with peroxynitrite reductase activity (Arasimowicz-Jelonek and Floryszak-Wieczorek, 2011). ONOO- is indirectly responsible for nitration reactions in macromolecules like proteins, lipids and nucleic acids. Protein tyrosine nitration is an irreversible, possibly inactivating posttranslational modification, which may initiate the degradation of the target protein (Kolbert et al., 2017). In the case of nucleic acids, $\mathrm{ONOO}^{-}$(or nitrogen oxides) is responsible for the nitration of guanine and related nucleosides, nucleotides either in their free or DNA and/or RNA embedded form (Ihara et al., 2011), resulting in the formation of mainly 8-oxoguanine (8-Oxy-G) and 8-nitroguanine (8$\left.\mathrm{NO}_{2}-\mathrm{G}\right) .8-\mathrm{NO}_{2}-\mathrm{G}$ incorporated in DNA may potentially be mutagenic or induce epigenetic changes; in RNA it may alter function and metabolism, and it may affect GTP-binding proteins and cGMP-dependent enzyme functions (Petřivalský and Luhová, 2020). In plant systems, nucleic acid nitration and its biological consequences are still poorly examined (Izbiańska et al., 2018; Andryka-Dudek et al., 2019). Recently, nitro-fatty acids (primarily nitro-linoleic acid and nitro-oleic acid) have been proposed as endogenous NO donors/reservoirs (Mata-Pérez et al., 2017; Vollár et al., 2020), which may liberate NO under specific circumstances and perform biological functions (Vollár et al., 2020) such as nitroalkylation of proteins (Aranda-Cano et al., 2019). Figure 1 gives an overview on the reactions and macromolecule modifications induced by NO and reactive nitrogen species. 
As can be seen from the above, NO is a molecule that operates an extensive signalling network and regulates growth, development and stress responses in plants. It is therefore not surprising that plant physiological studies in association with nanomaterials have been involving NO in recent years. This review aims to give an overview about the current literature regarding plant nanobiology involving NO.

\section{The involvement of NO in responses to nanomaterials}

\subsection{Nanomaterial-induced alterations of endogenous NO metabolism and signalling in plants}

\subsubsection{NO is involved in chitosan nanoparticle-triggered innate immunity in plants}

The natural biopolymer chitosan has been reported to induce disease resistance in plant-pathogen systems. The beneficial effects of chitosan on the plant immune system can be further improved by using its nanoparticle form (CNP). The deacetylation degree and the molecular weight of chitosan can be modulated to achieve different physicochemical properties. Nano-chitosan has different size, surface area, ion structure, lower phytotoxicity but better bioactivity, biocompatibility, and biodegradability as compared to chitosan. Due to these beneficial properties, CNPs as pesticides have potential for agricultural applications. Nitric oxide has long been known as a regulator of pathogen defence responses in plants (Durner et al., 1998; Delledonne et al., 1998; Wang et al., 2009; Yun et al., 2011; Trapet et al., 2015; Skelly et al., 2019). Recently, Chandra et al., (2017) examined the involvement of the NO signal in CNP-triggered innate immunity in tea (Camellia sinensis). In this study, leaves of Camellia were subjected to spherical CNPs $(0.001 \%)$ with an average diameter of $90 \mathrm{~nm}$. The nano form of chitosan showed more intense bioaccumulation in tea leaves compared to regular chitosan, which may be the reason for the greater inducing effect of the former on defence enzymes like peroxidase (POX), polyphenol oxidase (PPO), phenylalanine ammonia lyase (PAL), superoxide dismutase (SOD) and catalase (CAT). The amount of phenolic components (e.g. gallic acid, epichatechin) and the expression of defence-related genes (e.g. genes involved in flavonoid biosynthesis or antioxidant mechanisms) was increased to a higher extent by CNP compared to chitosan, supporting the view that CNP is an effective inducer of plant defence. Both CNP and chitosan treatments induced an increase in NO level in tea leaves, and NO scavenging by the application of 2-(4-carboxyphenyl)4,4,5,5-tetramethylimidazoline-1-oxyl-3-oxide (cPTIO) or the mammalian NOS inhibitor L$\mathrm{N}^{\mathrm{G}}$-nitro arginine methyl ester (L-NAME) notably mitigated the inducer effect of CNP on 
defence-related enzymes and genes and also on secondary metabolite production, indicating that CNP-induced NO accumulation is an essential contributor to the development of innate immunity.

Based on the previously observed anti-fungal properties of CNPs (Saharan et al., 2015; Manicandan and Sathiyabama, 2016; Sathiyabama and Parthasarathy, 2016), Siddaiah et al. (2018) studied the involvement of the NO signal in the CNP-triggered immune response of pearl millet against downy mildew. In contrast to the previous study, where the CNP solution was applied to the leaves of a healthy plant, seeds were incubated with CNP solutions of different concentrations, and the positive effect of CNP on germination and seedling viability was demonstrated. In pre-treated and then fungal-infected pearl millet seedlings, CNP seed treatment was shown to increase systemic resistance. This CNP-induced systemic resistance was mainly achieved by activating defence enzymes (e.g. PAL, PPO, POX, SOD, CAT) and by enhancing the transcription of corresponding genes as well as the pathogenesis-related 1 and 5 (PR1 and PR5) genes. Although the NO-inducing effect of CNP was not demonstrated in this work, NO quenching significantly inhibited the enhancement of the above defence processes by CNP, demonstrating the role of NO in the antifungal effect of CNP.

Further studying the involvement of NO in the development of CNP-induced pathogen defence is a promising research direction, as the results may contribute to improving the agricultural use of CNPs.

\subsubsection{Carbon nanotubes-promoted stress tolerance involves NO signalling}

Carbon nanotubes (CNTs) are characterized by large specific surface area, high electrical conductivity, thermal stability and hydrophobicity, and due to these desirable features CNTs are manufactured in high quantities worldwide. With the remarkable advancement of nanotechnology, carbon nanotubes have been heavily used for numerous applications in different areas of the plant system. Recently, the interest in applying CNTs to crops for agricultural purpose is constantly growing, since CNTs have a potential to be utilized as directed delivery systems for pesticides, fertilizer and other chemical compounds. The properties of CNTs are influenced by their structure. Different CNTs (e.g. single-walled carbon nanotubes, SWCNTs; multi-walled carbon nanotubes, MWCNTs) have distinct properties and application potentials (Sinha and Yeow, 2005; Sinha et al., 2006; Saifuddin et al., 2013; Eatemadi et al., 2014; Sarangdevot and Sonigara, 2015). 
It is known that MWCNTs have positive effects on germination, biomass production, and stress tolerance in several plant species (Mondal et al., 2011; Wang et al., 2012; Khodakovskaya et al., 2013; Lahiani et al., 2013; Tiwari et al., 2014; Martínez-Ballesta et al., 2016; Hatami et al., 2017). Similarly, NO has been proven to intensify tolerance in multiple plant-stress systems (reviewed in Feigl and Kolbert, 2020). The first research showing a correlation between CNPs and NO was published by Karami and Sepehri (2018a), who reported that sodium nitroprusside (SNP) and MWCNTs, used either separately or together exert beneficial effects on barley germination under control conditions and also during drought or salt stress. The authors concluded that NO promotes the beneficial effect of MWCNTs on seed germination and ameliorates the adverse effect of high MWCNT doses. However, this study did not investigate the putative effect of MWCNT on endogenous NO levels, and did not provide evidence for the involvement of the NO signal in MWCNTinduced salt and drought tolerance. These gaps in knowledge have been filled in by the comprehensive study of Zhao et al., (2019), who studied MWCNT-induced salt tolerance and the involvement of NO in it in rapeseed (Brassica napus) and thale cress (Arabidopsis thaliana). It was observed that MWCNTs are internalized into plant cells and are translocated from root to shoot in Brassica seedlings. Moreover, the application of MWCNTs could effectively mitigate growth inhibition induced by salt, and resulted in high NO levels in roots. Reduction of the NO level by cPTIO in MWCNT-subjected plants terminated the beneficial effect of the nanoparticles on seedling growth. Using pharmacological treatments and mutant analyses (nial/2 and noal Arabidopsis with reduced NO levels), the authors suspected that NR may be partially involved in NO production during MWCNT-induced salt tolerance. As for the mechanism of NO action, the study proved that salt-triggered and MWCNT-alleviated oxidative stress depends on the presence of NO in Brassica roots. Additionally, MWCNTinduced NO accumulation may activate antioxidant enzymes, as suggested by the fact that cPTIO negatively affects MWCNT-enhanced activities and gene expressions of APX and SODs. The authors also observed that disturbed ion homeostasis under salt stress was improved by the MWCNT-NO pathway. These results were strengthened by genetic experiments using NO-deficient Arabidopsis lines. The authors conclude that NR-dependent NO is, at least partially, required for MWCNT-triggered salt tolerance via re-establishing redox and ion homeostasis. Additionally, the same research group recently reported that MWCNT exposure of tomato seedlings induced lateral root (LR) formation and concomitant NO production (Cao et al., 2020). Similarly to Brassica seedlings (Zhao et al., 2019), MWCNTs were also absorbed by tomato roots, as MWCNTs were demonstrated by TEM to 
be associated with the cell wall of root cells. When NO was scavenged by cPTIO, MWCNTinduced LR formation was significantly inhibited, indicating that the NO signal is necessary for the beneficial effect of MWCNT on LR emergence of tomato. Further results indicated that MWCNT-induced NR activity may be responsible for endogenous NO production in tomato roots (Cao et al., 2020).

From these results it can be seen that the beneficial effects of MWCNT on stress tolerance and root development are associated with endogenous NO signalling; however, further research is needed to better understand the molecular details of the MWCNT-NO signal pathway.

\subsubsection{NO signalling contributes to the phytotoxicity of metal-oxide nanoparticles}

Recent reviews (Khan et al., 2017; Marslin et al., 2017) have already discussed that some of the metal oxide $\left(\mathrm{ZnO}, \mathrm{Fe}_{3} \mathrm{O}_{4}\right)$ NPs may provoke oxidative stress in plant cells, whereas others containing basically non-essential metals (e.g. $\mathrm{TiO}_{2}$ or $\mathrm{Al}_{2} \mathrm{O}_{3}$ ) can act positively on plant growth or stress tolerance. Nonetheless, there are only few data about the impact of metal oxide NPs on the homeostasis of reactive nitrogen species (RNS), especially NO. Here we overview some cases showing the diverse influences of these NPs depending on the metallic component.

Regarding essential metals like zinc $(\mathrm{Zn})$ there are two considerable publications. Chen et al. (2015) reported that elevated NO content was detected both in roots and shoots of rice after $\mathrm{ZnO} \mathrm{NP}$ application $\left(250 \mathrm{mg} \mathrm{L}^{-1}\right)$, but $\mathrm{NO}$ generation was more explicit when 10 $\mu \mathrm{M}$ SNP was also added. The elevated endogenous NO due to SNP application diminished the $\mathrm{ZnO}$ NP-induced toxicity symptoms including root and shoot growth inhibition or reactive oxygen species (ROS) overproduction. This study suggests that the involvement of NO in enhancing ZnO NP tolerance is based on its cross-talk with ROS and the antioxidant defence system. Recently Molnár et al. (2020a) investigated rapeseed (Brassica napus) and Indian Mustard (Brassica juncea) seedlings exposed to ZnO NPs ( 8 nm, 25 or $100 \mathrm{mg} / \mathrm{L})$. Whereas the low dose of $\mathrm{ZnO}$ NP had positive effects, the higher concentration $(100 \mathrm{mg} / \mathrm{L})$ was toxic to both species. $\mathrm{ZnO}$ NPs elevated $\mathrm{O}_{2}{ }^{--}$content in the root tips due to the increased activity of NADPH oxidase, and hydrogen peroxide $\left(\mathrm{H}_{2} \mathrm{O}_{2}\right)$ homeostasis was also altered. In more tolerant $B$. juncea exposed to $25 \mathrm{mg} / \mathrm{L} \mathrm{ZnO} \mathrm{NP}$, the tissue level of GSNO significantly decreased and the endogenous NO level increased, but there was no evidence to show that the relationship between NO and GSNO levels might be affected by ZnO NPs. Since the changes 
of oxidative stress parameters were similar in both species, the authors suppose that the difference between the $\mathrm{ZnO}$ NP tolerances of the two Brassica species is more likely related to nitrosative than to oxidative signalling. Using ZnO NPs with larger size ( 45 nm, 25 or $100 \mathrm{mg} / \mathrm{L}$ ), Molnár et al. (2020b) detected cell wall modifications in B. napus where the lack of the nitrosative response was associated with $\mathrm{ZnO} \mathrm{NP}$ tolerance.

Another microelement, cobalt (Co) in the form of metal oxide was also examined. In the study of Faisal et al. (2016) cobalt oxide nanoparticles $\left(\mathrm{Co}_{3} \mathrm{O}_{4} \mathrm{NPs}\right)$ were reported to cause phytotoxicity expressed in retarded root elongation, and this kind of NP can massively adsorb to the root surface (Ghodake et al., 2011). In this study, eggplant (Solanum melongena) seeds treated with $\mathrm{Co}_{3} \mathrm{O}_{4} \mathrm{NPs}(1.0 \mathrm{mg} / \mathrm{ml})$ for 7 days exhibited lower germination rate and root growth compared to the control. Additionally, in protoplasts derived from the root, endogenous NO content was shown to be elevated by all NP treatments. Since several studies have demonstrated that NO participates in cell death induction due to the disturbance of mitochondrial functions and ROS overproduction, it is not surprising that $\mathrm{Co}_{3} \mathrm{O}_{4}$ NPs cause stunted root development.

In the paper of Saquib et al. (2016) the impact of ferric oxide nanoparticles $\left(\mathrm{Fe}_{2} \mathrm{O}_{3}\right.$ NPs) on radish (Raphanus sativus) was analysed. The application of $\mathrm{Fe}_{2} \mathrm{O}_{3} \mathrm{NPs}$ provoked root shortening and reduced the seed germination rate due to the increased level of reactive ROS and NO. A dose-dependent induction of the antioxidant enzymes like CAT, SOD and glutathione $(\mathrm{GSH})$ as well as lipid peroxidation were also demonstrated. These results suggest that metal oxide NPs containing essential microelement may cause severe nitrooxidative damage in plants.

At the same time, metal oxide NPs incorporating non-essential metals like aluminium (Al) or titanium (Ti), seem to be beneficial for plants, even under stress conditions. When Arabidopsis thaliana was exposed to $98 \mu \mathrm{M} \mathrm{Al}_{2} \mathrm{O}_{3} \mathrm{NPs}$, the NO content in roots showed no changes compared to the control, whereas ionic $\mathrm{Al}\left(\mathrm{AlCl}_{3}\right)$ at $196 \mu \mathrm{M}$ concentration resulted in significant inhibition of root growth accompanied by NO accumulation (Jin et al., 2017). Moreover, previously Poborilova et al. (2013) used tobacco BY-2 cell suspension culture as plant cell model, and exposed it to $\mathrm{Al}_{2} \mathrm{O}_{3} \mathrm{NPs}\left(10,20,50\right.$ and $\left.100 \mu \mathrm{g} \mathrm{mL}^{-1}\right)$ for $12-96 \mathrm{~h}$. The levels of RNS (endogenous NO) and $\operatorname{ROS}\left(\mathrm{H}_{2} \mathrm{O}_{2}\right.$ and $\mathrm{O}_{2}{ }^{-}$) showed time- and dose-dependent enhancement. Besides, elevated malondialdehyde (MDA) production was observed, which resulted in plasma membrane damage and, finally, programmed cell death. Nanomaterialinduced NO production in different plant species and experimental systems is summarized in Table 1. 
Stress tolerance improvement by the application of metal oxide NPs can be a future perspective in agriculture. Barley was exposed to salt stress (100 or $200 \mathrm{mM} \mathrm{NaCl})$, and the potentially positive impact of titanium dioxide $\left(\mathrm{TiO}_{2}\right) \mathrm{NPs}$ at 500, 1000 and $2000 \mathrm{mg} \mathrm{kg}^{-1}$ (pot experiment) was tested (Karami and Sepehri, 2018b); moreover, exogenous NO was added in the form of SNP $(100 \mu \mathrm{M})$. $\mathrm{TiO}_{2}$ NPs at all concentrations had a beneficial effect on plant growth and photosynthetic activity in salt-stressed plants. SNP itself also improved the activity of antioxidant enzymes like SOD, CAT and APX, whereas $\mathrm{TiO}_{2}$ together with SNP proved to be effective in decreasing MDA and $\mathrm{H}_{2} \mathrm{O}_{2}$ levels, which are the indicators of oxidative stress induced by salinity. In cadmium-stressed wheat the joint application of SNP and $\mathrm{TiO}_{2}$ NPs could moderate the negative effect of $\mathrm{Cd}$ on seed germination and seedling growth, suggesting their promising potential in the alleviation of the negative effects induced by Cd stress (Faraji et al., 2018). This theory was further reinforced by the observation that the combined application of exogenous $\mathrm{NO}$ and $\mathrm{TiO}_{2}$ NPs was able to protect wheat seedlings against oxidative stress induced by drought (Faraji and Sepehri, 2020). In this study $100 \mu \mathrm{M}$ SNP with $2000 \mathrm{mg} / \mathrm{kg} \mathrm{TiO}_{2} \mathrm{NP}$ reversed seedling growth inhibition, and increased the amount of total soluble proteins and SOD activity, together with photosynthetic activity, leading to reduced $\mathrm{H}_{2} \mathrm{O}_{2}$ content and lipid peroxidation under drought stress. Additionally, the application of $15 \mathrm{mg} \mathrm{L}^{-1} \mathrm{TiO}_{2}$ NPs to drought-stressed bean (Vicia faba) induced NR activity and consequently increased the endogenous NO level in the seedlings (Khan et al. 2020). This higher NO level fortified the enzymatic (SOD, CAT) and non-enzymatic (ascorbate and GSH) antioxidant defence system and attenuated the generation of $\mathrm{H}_{2} \mathrm{O}_{2}, \mathrm{O}_{2}{ }^{--}$ and lipid peroxides. Based on the above studies exogenous $\mathrm{NO}$ and $\mathrm{TiO}_{2}$ NPs have a mutually reinforcing, positive effect (summarized in Table 2), which could be a powerful tool to help plants cope with abiotic stressors; however, these results should be confirmed by examining other metal oxide NPs and NO donors.

\subsection{Protective effect of exogenous chemical NO donors on nanoparticle-induced stress in plants}

Exogenously applied NO (mainly in the form of SNP) is well known to be able to alleviate the negative effects of various abiotic stresses, including high concentrations of elements (heavy metals included) (Terrón-Camero et al., 2019), although very little is known about the protective effect of exogenous NO on NP-induced stress in plants. So far, only three studies have dealt with the topic in question, all of them using SNP as a NO donor agent. 
Chen et al. (2015) examined the effect of SNP on $\mathrm{ZnO}$ nanoparticle-stressed rice (Oryza sativa L.) seedlings, and found that $10 \mu \mathrm{M}$ SNP was able to effectively reduce toxicity symptoms. Exogenous NO was able to overturn the $\mathrm{ZnO}$ NP-induced growth inhibition, by the reduction of $\mathrm{Zn}$ accumulation. Moreover, SNP mitigated ROS accumulation by the elevation of GSH level and SOD activity and reversing the $\mathrm{ZnO} \mathrm{NP}$-induced decrease in POX, CAT and APX activities. In agreement with the activity results, gene expression of the above-mentioned antioxidant enzymes was upregulated by SNP under ZnO NP stress. Moreover, NO overproducer (noel) and deficient (noal) rice lines were also tested, proving that high NO content can increase $\mathrm{ZnO}$ NP tolerance by upregulating the gene expression of antioxidant enzymes.

Tripathi et al. (2017a) also studied the effect of $\mathrm{ZnO} \mathrm{NP}$, but on wheat (Triticum aestivum L.) seedlings, and found that $100 \mu \mathrm{M}$ SNP successfully enhanced their ZnO NP tolerance through two mechanisms. Firstly, exogenous NO lowered Zn content in the vascular tissues, resulting in reduced oxidative stress and lipid peroxidation. Secondly, in the background of decreased oxidative stress, upregulation of the enzymes (APX, glutathione reductase (GR), dehydroascorbate reductase (DHAR), monodehydroascorbate reductase (MHAR)) of the ascorbate-glutathione cycle was observed, resulting in an enhanced ascorbate/dehydroascorbate and reduced/oxidized glutathione ratio, providing a higher protection against $\mathrm{ZnO} \mathrm{NP}$-induced oxidative stress.

Comparing the two similar studies, it is conspicuous that there was a ten-fold difference in the effective SNP concentrations, despite working with hydroponically-grown seedlings in both experimental setups. This difference may be due to differences in treatment conditions. Namely, rice plants were subjected to both SNP and ZnO NPs at the same time (Chen et al., 2015), whereas wheat plants were treated with SNP for 24 hours prior to NP supplementation (Tripathi et al., 2017a).

In the third and last study, also by Tripathi et al. (2017b) the effect of exogenous NO on silver nanoparticle (Ag NP)-induced stress in pea (Pisum sativum L.) seedlings was studied, and it was found that $100 \mu \mathrm{M}$ SNP was able to effectively decrease the negative effects induced by Ag NP. Similarly to the previous studies, exogenous NO was able to decrease Ag accumulation, oxidative stress and lipid peroxidation caused by Ag NP stress. NO supplementation improved photosynthetic activity together with the enzymatic (APX, SOD, GR, DHAR) and non-enzymatic (total ascorbate and GSH content) antioxidant defence system. It was also found that SNP treatment was able to ameliorate Ag NP-related morphological toxicity symptoms in leaves, such as abnormal parenchymatic differentiation 
and epidermis development, and also in roots, where Ag NP-inhibited root hair formation was reversed by NO supplementation.

Based on the (scant) information available, exogenous NO in the form of SNP supplementation protects plants from the consequences of NP-induced stress (summarized in Table 2). Based on the results, at least two main mechanisms of NO action can be assumed. Nitric oxide decreases metal uptake (liberated from the NPs) and reduces oxidative stress through the upregulation of both enzymatic and non-enzymatic antioxidant capacity. The molecular mechanisms of NO effects on metal uptake and antioxidants like $S$-nitrosation or protein nitration are still not known and need to be further elucidated. Although, these mechanisms may be similar to the much better studied effects of exogenous NO on plants subjected to "standard" heavy metal stress (reviewed by Terrón-Camero et al., 2019).

\section{NO-releasing nanoparticles and their effects on plants}

Although SNP is widely used as supported by the research presented above, the reliability of such chemical NO donors in plant biology is limited by their putative side effects and instability. The production and use of NO donor molecules in the form of NPs can bring a breakthrough in this area. Such NO-releasing NPs have already been extensively studied in clinical research (Zhou et al., 2016; Xu et al., 2019), whereas in plants, so far, only a few reports describe their effects.

First, in 2015, Pereira et al. prepared and applied on plants GSNO-containing alginate/chitosan nanoparticles with a hydrodynamic diameter of 300-550 nm. As for NO releasing capacity, the NPs resulted in a NO burst in the first five hours, then caused further increase in NO in the next 24 hours. The rate of NO release was proportional to the concentration of GSNO-containing alginate/chitosan nanoparticles. At a concentration of 10 mmol/L, NPs released approx. $2.5 \mathrm{mmol} / \mathrm{L}$ NO within 24 hours. However, the NPs produced did not have a significant effect either on soybean (Glycine max) or on maize (Zea mays), which on the one hand means that the NPs are non-toxic, and on the other hand draws attention to the fact that it is worth examining the effects in a wider concentration range to explore their assumed positive effect related to stress response/tolerance and their transport and fate in different plant species.

In the first relevant study, Oliveira et al., (2016) used the low-molecular weight NO donor, S-nitroso-mercaptosuccinic acid (S-nitroso-MSA) belonging to the class of RSNOs. Snitroso-MSA was encapsulated by chitosan, yielding S-nitroso-MSA CS NPs with a 
hydrodynamic diameter range between 20 and $56 \mathrm{~nm}$. In the first 12 hours, approx. 70-80 $\mu \mathrm{M}$ NO was liberated by $1000 \mu \mathrm{M}$ S-nitroso-MSA CS NPs, which is much less than the amount of NO liberated by free S-nitroso-MSA. Maize plants were exposed to $\mathrm{NaCl}$ plus S-nitrosoMSA CS NPs in sand culture. S-nitroso-MSA CS NPs $(100 \mu \mathrm{M})$ further increased salttriggered elevation of SNO content in maize leaves, which in turn ameliorated the growth reduction, photosynthetic inhibition and chlorophyll loss induced by salt stress. The ineffectiveness of NPs containing non-nitrosated MSA suggests that the salt stressameliorating effect of S-nitroso-MSA-CS NPs is due to the released NO. The authors noted that the uptake, translocation and accumulation of S-nitroso-MSA-CS NPs in plant tissues needs to be studied in the future.

In a recent study, GSNO was encapsulated in CS NPs, and the resulting GSNO CS NPs with a hydrodynamic size $\sim 104 \mathrm{~nm}$ were shown to release NO in vitro, although the rate of NO liberation was approx. 50\% less than in case of free GSNO (Silveira et al., 2019). This indicates that encapsulation prevents GSNO from transient decomposition. Interestingly, when applied on sugarcane plants, both the free and the NP-form of GSNO increased the SNO level to a similar extent in the leaves. These observations emphasize that GSNO CS NPs have more advantageous properties (enhanced stability with similar NO-liberating capacity) than free GSNO. Sugarcane plants were exposed to polyethylene glycol (PEG)induced drought decreasing $\mathrm{CO}_{2}$ assimilation, transpiration, PSII-related photosynthetic capacity, relative water content, chlorophyll concentration as well as biomass production. Plants sprayed with free GSNO or GSNO CS NPs showed an improvement in the abovementioned parameters, indicating that exogenous GSNO (both free and NP form) positively regulates drought stress tolerance of sugarcane plants. There was no significant difference between the effects of free GSNO and the NP form except for the root/shoot ratio, where the GSNO CS NPs caused a greater increase, suggesting its potential use in agricultural/cultivation methods.

In their recent study, Lopes-Oliveira et al., (2019) prepared S-nitroso-MSA CS NPs with 35-40 nm hydrodynamic size according to their previous method (Oliveira et al. 2016). Two-phased NO release was observed in vitro, where the first NO burst occurred after 15 min in light and after $50 \mathrm{~min}$ in the dark and the second phase resulted in a steady-state NO level. Similarly to previous observations, the NO-releasing capacity of S-nitroso-MSA CS NPs was lower than that of free S-nitroso-MSA. Treatments with $2 \mathrm{mM} \mathrm{S-nitroso-MSA} \mathrm{CS} \mathrm{NPs,} \mathrm{free}$ S-nitroso-MSA or MSA NPs were applied via the growth substrate on Heliocarpus popayanensis and Cariniana estrellensis seedlings cultivated in an outdoor nursery. The 
concentration of SNO increased significantly only in the case of C. estrellensis leaves, although MSA NPs also caused SNO level increase, which makes the NO specificity of the NP effect uncertain. Additionally, the treatments did not modify SNO levels in the leaves but increased most of the observed growth parameters in $H$. popayanensis. As for C. estrellensis, none of the treatments affected growth despite the S-nitroso-MSA CS NP-triggered SNO increase. This indicates the lack of a connection between SNO/NO levels and growth induction. Regarding photosynthesis, S-nitroso-MSA CS NPs were ineffective in both species. Furthermore, a slight reduction in phenolics and a moderate increase in $\mathrm{H}_{2} \mathrm{O}_{2}$ level was observed in S-nitroso-MSA CS NPs-treated H. popayanensis, whereas other parameters showed no relevant modifications as a result of NO-releasing NP treatment. According to the authors, S-nitroso-MSA CS NP treatment may be a powerful strategy to develop seedling acclimation. However, it is important to highlight that S-nitroso-MSA CS NPs were not effective in increasing SNO levels in all cases, the growth-promoting effect was speciesdependent and there was no correlation between SNO levels and growth induction.

The results available so far will need to be supplemented in the future, but based on the above, it can be concluded that encapsulation of NO donors provides better stability against thermo- and photolysis, better storage, and the NPs are able to control the release of NO in vitro within a similar order of magnitude but to a lesser extent than the free NO donors. Treatment of plants (via foliar spray or via the root system) in most cases demonstrably increases SNO levels and alleviates stress-induced damages in the plant species studied so far (summarized in Table 3). Therefore, it is necessary to further investigate and critically evaluate these promising combinations of NO donors and nanomaterials prior to use.

\section{NO-detection in plants with nanoparticle-based sensors}

The other relevant methodological problem in plant NO research is quantification of the free radical within plant tissues. The most common method available to most laboratories is microscopic detection of NO by diaminofluorescein probes (Kojima et al., 1998), but this approach does not provide quantitative results. The development of NO-specific nanosensors can make progress on this issue due to their favourable characteristics such as being nondestructive, minimally invasive, and capable of real-time analysis (Iverson et al., 2018). However, only one study has been published to date in which a smart NP-based sensor detecting NO has been applied in plants (Giraldo et al., 2014). Previously, 3,4- 
diaminophenyl-functionalized dextran (DAP-dex) wrapped in single-walled carbon nanotubes (SWNTs) was synthetized, and it was observed that the near-infrared fluorescence of $\mathrm{SWNT}_{\mathrm{DAP}-\mathrm{dex}}$ is rapidly, directly and selectively quenched by NO (Kim et al., 2009). It was shown that SWNT penetrates lipid bilayers and internalizes chloroplasts, which made it possible to sense chloroplast-localized NO by SWNT. Arabidopsis leaf was infiltrated with NO-sensing SWNTs and was excited by epifluorescence microscope following the addition of dissolved NO solution. Based on the degree of fluorescence quenching, the level of NO could be estimated. Such nanosensors allow the translation of plant chemical signals (e.g. NO) into digital information that can be monitored by electronic devices in real time. Smart plant sensors can be used for the evaluation of the health status of plants in order to improve plant productivity, and therefore they can have a great potential in agricultural practices (Giraldo et al., 2019).

\section{Conclusion and future perspectives}

Diverse types of nanomaterials, e.g. chitosan NP, nanotubes, metal-oxide NP, and NOreleasing NP promote NO production within the plant body. In some cases, NR was associated with NP-induced NO production. In general, endogenous NO has a positive effect by activating the antioxidant system (enzymatic and non-enzymatic) and contributing to the beneficial effect of nanomaterials by eliciting immune response, by enhancing tolerance in plants exposed to abiotic stress or by promoting growth and development. Several studies focus on the ameliorating effect of chemical NO donors on NP phytotoxicity. In these cases, NO has been observed to exert its effect both by inducing the antioxidant system and reducing metal uptake (Figure 2). Overall, nanoscience in plant systems is a novel research field. The few available literature data need to be expanded by molecular studies. The molecular mechanism of NO signalling (e.g. $S$-nitrosation, tyrosine nitration, lipid nitration etc.) behind the effects of NPs on plant physiology need to be closely investigated by future studies. From a practical point of view, testing of NO-releasing NPs on plants is highly relevant, as those can replace chemical NO donors both in plant research and in possible agricultural applications. Equally important is that NO-specific nanosensors may promise methodological development in plant research and in nano-agriculture, thus their testing in plants needs to be continued. 


\section{Acknowledgements}

This work was financed by the National Research, Development and Innovation Office [Grant no. NKFI-8, K129511; NKIFH PD 131589]. Zs. K. was supported by the János Bolyai Research Scholarship of the Hungarian Academy of Sciences [Grant no. BO/00751/16/8].

\section{Author Contribution}

ZSK: Conceptualization, Visualization, Writing - original draft, Writing - review \& editing; RSZ: Writing - original draft; GF: Writing - original draft; ZK: Writing - review \& editing; AR: Writing - original draft, Writing - review \& editing. 


\section{References}

Andryka-Dudek P, Ciacka K, Wiśniewska A, Bogatek R, Gniazdowska A. 2019. Nitric oxide-induced dormancy removal of apple embryos is linked to alterations in expression of genes encoding ABA and JA biosynthetic or transduction pathways and RNA nitration. International Journal of Molecular Sciences doi: 10.3390/ijms20051007

Aranda-Caño L, Sánchez-Calvo B, Begara-Morales JC, Chaki M, Mata-Pérez C, Padilla MN, Valderrama R, Barroso JB. 2019. Post-translational modification of proteins mediated by nitro-fatty acids in plants: nitroalkylation. Plants (Basel) doi: 10.3390/plants8040082

Arasimowicz-Jelonek M, Floryszak-Wieczorek J. 2011. Understanding the fate of peroxynitrite in plant cells-From physiology to pathophysiology. Phytochemistry 72, 681-688.

Barroso JB, Corpas FJ, Carreras A, et al. 2006. Localization of S-nitrosoglutathione and expression of S-nitrosoglutathione reductase in pea plants under cadmium stress. Journal of Experimental Botany 57, 1785-1793.

Beckman JS, Beckman TW, Chen J, Marshall PA, Freeman BA. 1990. Apparent hydroxyl radical production by peroxynitrite: implication for endothelial injury from nitric oxide and superoxide. Proceedings of the National Academy of Sciences of the United States of America 87, 1620-1624.

Begara-Morales JC, Chaki M, Valderrama R, et al. 2018. Nitric oxide buffering and conditional nitric oxide release in stress response. Journal of Experimental Botany 69, 3425-3438.

Bethke PC, Badger MR, Jones RL. 2004. Apoplastic synthesis of nitric oxide by plant tissues. The Plant Cell 16, 332-341.

Cao Z, Zhou H, Kong L, Li L, Wang R, Shen W. 2020. A novel mechanism underlying multi-walled carbon nanotube-triggered tomato lateral root formation: the involvement of nitric oxide. Nanoscale Research Letters doi: 10.1186/s11671-020$3276-4$

Chamizo-Ampudia A, Sanz-Luque E, Llamas A, Galvan A, Fernandez E. 2017. Nitrate reductase regulates plant nitric oxide homeostasis. Trends in Plant Science 22, 163174. 
Chamizo-Ampudia A, Sanz-Luque E, Llamas Á, Ocaña-Calahorro F, Mariscal V, Carreras A, Barroso JB, Galván A, Fernández E. 2016. A dual system formed by the ARC and NR molybdoenzymes mediates nitrite-dependent NO production in Chlamydomonas. Plant, Cell \& Environment 39, 2097-2107.

Chandra S, Chakraborty N, Panda K, Acharya K. 2017. Chitosan-induced immunity in Camellia sinensis (L.) O. Kuntze against blister blight disease is mediated by nitricoxide. Plant Physiology and Biochemistry 115, 298-307.

Chen J, Liu X, Wang C, et al. 2015. Nitric oxide ameliorates zinc oxide nanoparticlesinduced phytotoxicity in rice seedlings. Journal of Hazardous Materials 297, 173-182.

Corpas FJ, Chaki M, Fernandez-Ocana A, et al. 2008. Metabolism of reactive nitrogen species in pea plants under abiotic stress conditions. Plant and Cell Physiology 49, 1711-1722.

Delledonne M, Xia Y, Dixon RA, Lamb C. 1998. Nitric Oxide functions as a signal in plant disease resistance. Nature 394, 585-588.

Durner J, Wendehenne D, Klessig DF. 1998. Defense gene induction in tobacco by nitric oxide, cyclic GMP, and cyclic ADP-ribose. Proceedings of the National Academy of Sciences of the United States of America 95, 10328-10333.

Eatemadi A, Daraee H, Karimkhanloo H, Kouhi M, Zarghami N, Akbarzadeh A, Abasi M, Hanifehpour Y, Joo SW. 2014. Carbon nanotubes: properties, synthesis, purification, and medical applications. Nanoscale Research Letters doi: $10.1186 / 1556-276 X-9-393$

Ellenbecker MJ, Tsai C S-J. 2015. Exposure assessment and safety considerations for working with engineered nanoparticles. Oxford: Wiley-Blackwell.

Faisal M, Saquib Q, Alatar AA, et al. 2016. Cobalt oxide nanoparticles aggravate DNA damage and cell death in eggplant via mitochondrial swelling and NO signaling pathway. Biological Research doi: 10.1186/s40659-016-0080-9

Faraji J, Sepehri A. 2020. Exogenous nitric oxide improves the protective effects of $\mathrm{TiO}_{2}$ nanoparticles on growth, antioxidant system, and photosynthetic performance of wheat seedlings under drought stress. Journal of Soil Science and Plant Nutrition 20, 703-714. 
Faraji J, Sepehri A, Salcedo-Reyes JC. 2018. Titanium dioxide nanoparticles and sodium nitroprusside alleviate the adverse effects of cadmium stress on germination and seedling growth of wheat (Triticum aestivum L.). Universitas Scientiarum 23, 61-87.

Feigl G, Kolbert Zs. 2020. Role of nitric oxide in plant abiotic stress tolerance. In: Khan MIR, Singh A, Poór P, eds. Improving Abiotic Stress Tolerance in Plants. Taylor \& Francis Group

Foster, MW, McMahon TJ, Stamler JS. 2003. S-nitrosylation in health and disease. Trends in Molecular Medicine 9, 160-168.

Fraceto LF, Grillo R, de Medeiros GA, Scognamiglio V, Rea G and Bartolucci C. 2016. Nanotechnology in agriculture: which innovation potential does it have? Frontiers in Environmental Science doi: 10.3389/fenvs.2016.00020

Ghodake G, Seo YD, Lee DS. 2011. Hazardous phytotoxic nature of cobalt and zinc oxide nanoparticles assessed using Allium cepa. Journal of Hazardous Materials 186, $952-$ 955.

Giraldo JP, Landry MP, Faltermeier SM, et al. 2014. Plant nanobionics approach to augment photosynthesis and biochemical sensing. Nature Materials doi: 10.1038/NMAT3890

Giraldo JP, Wu H, Newkirk GM, Kruss S. 2019. Nanobiotechnology approaches for engineering smart plant sensors. Nature Nanotechnology 14, 541-553.

Hao F, Zhao S, Dong H, Zhang H, Sun L, Miao C. 2010. Nia1 and Nia2 are involved in exogenous salicylic acid-induced nitric oxide generation and stomatal closure in Arabidopsis Journal of Integrative Plant Biology 52, 298-307.

Hatami M, Hadian J, Ghorbanpour M. 2017. Mechanisms underlying toxicity and stimulatory role of single-walled carbon nanotubes in Hyoscyamus niger during drought stress simulated by polyethylene glycol. Journal of Hazardous Materials 324, 306-320.

Hebelstrup KH, Hunt P, Dennis E, Jensen SB, Jensen EØ. 2006. Hemoglobin is essential for normal growth of Arabidopsis organs. Physiologia Plantarum 127, 157-166.

Hogg N. 2000. Biological chemistry and clinical potential of S-nitrosothiols. Free Radical Biology and Medicine, 28, 1478-1486. 
Ihara H, Sawa T, Nakabeppu Y, Akaike T. 2011. Nucleotides function as endogenous chemical sensors for oxidative stress signaling. Journal of Clinical Biochemistry and Nutrition 48, 33-39.

Iverson NM, Hofferber EM, Stapleton JA. 2018. Nitric oxide sensors for biological applications. Chemosensors doi: 10.3390/chemosensors6010008

Izbiańska K, Floryszak-Wieczorek J, Gajewska J, Meller B, Kuźnicki D, ArasimowiczJelonek M. 2018. RNA and mRNA nitration as a novel metabolic link in potato immune response to Phytophthora infestans. Frontiers in Plant Science doi: 10.3389/fpls.2018.00672

Jin Y, Fan X, Li X, Zhang Z, Sun L, Fu Z, Lavoie M, Pan X, Qian H. 2017. Distinct physiological and molecular responses in Arabidopsis thaliana exposed to aluminum oxide nanoparticles and ionic aluminum. Environmental Pollution 228, 517-527.

Karami A, Sepehri A. 2018a. Beneficial role of MWCNTs and SNP on growth, physiological and photosynthesis performance of barley under $\mathrm{NaCl}$ stress. Journal of Soil Science and Plant Nutrition 18, 752-771.

Karami A, Sepehri A. 2018b. Nano titanium dioxide and nitric oxide alleviate salt induced changes in seedling growth, physiological and photosynthesis attributes of barley. Zemdirbyste-Agriculture 105, 123-132.

Khalid K, Tan X, Zaid HFM, et al. 2020. Advanced in developmental organic and inorganic nanomaterial: a review. Bioengineered 11: 328-355.

Khan MN, Mobin M, Abbas ZK, AlMutairi KA, Siddiqui ZH. 2017. Role of nanomaterials in plants under challenging environments. Plant Physiology and Biochemistry 110, 194-209.

Khan MN, AlSolami MA, Basahi RA, Siddiqui MH, Al-Huqail AA, Abbas ZK, Siddiqui ZH, Ali HM, Khan F. 2020. Nitric oxide is involved in nano-titanium dioxideinduced activation of antioxidant defense system and accumulation of osmolytes under water-deficit stress in Vicia faba L. Ecotoxicology and Environmental Safety 190,10152 , in press

Khodakovskaya MV, Kim B-S, Kim JN, Alimohammadi M, Dervishi E, Mustafa T, Cernigla CE. 2013. Carbon nanotubes as plant growth regulators: effects on tomato growth, reproductive system, and soil microbial community. Small 9, 115-123. 
Kim J, Heller D, Jin H, Barone PW, Song C, Zhang J, Trudel LJ, Wogan GN, Tannenbaum SR, Strano MS. 2009. The rational design of nitric oxide selectivity in single-walled carbon nanotube near-infrared fluorescence sensors for biological detection. Nature Chemistry 1, 473-481.

Kojima H, Nakatsubo N, Kikuchi K, Kawahara S, Kirino Y, Nagoshi H, Hirata Y, Nagano T. 1998. Detection and imaging of nitric oxide with novel fluorescent indicators: diaminofluoresceins. Analitycal Chemistry 70, 2446-2453.

Kolbert Zs, Feigl G, Bordé Á, Molnár Á, Erdei L. 2017. Protein tyrosine nitration in plants: Present knowledge, computational prediction and future perspectives. Plant Physiology and Biochemistry 113, 56-63.

Kolbert Zs, Barroso JB, Brouquisse R, et al. 2019. A forty-year journey: the generation and roles of NO in plants. Nitric Oxide 93, 53-70.

Lahiani MH, Dervishi E, Chen J, Nima Z, Gaume A, Biris AS, Khodakovskaya MV. 2013. Impact of carbon nanotube exposure to seeds of valuable crops. ACS Applied Materials \& Interfaces 5, 7965-7973.

Leterrier M, Chaki M, Airaki M, Valderrama R, Palma JM, Barroso JB, Corpas FJ. 2011. Function of S-nitrosoglutathione reductase (GSNOR) in plant development and under biotic/abiotic stress. Plant Signaling \& Behavior, 6, 789-793.

Lindermayr C. 2018. Crosstalk between reactive oxygen species and nitric oxide in plants: key role of S-nitrosoglutathione reductase. Free Radical Biology and Medicine, 122, 110-115.

Lopes-Oliveira PJ, Gomes DG, Pelegrino MT, Bianchini E, Pimenta JA, Stolf-Moreira R, Seabra AB, Oliveira HC. 2019. Effects of nitric oxide-releasing nanoparticles on neotropical tree seedlings submitted to acclimation under full sun in the nursery. Scientific Reports doi: 10.1038/s41598-019-54030-3

Lu S, Zhuo C, Wang X, Guo Z. 2014. Nitrate reductase (NR)-dependent NO production mediates ABA- and $\mathrm{H}_{2} \mathrm{O}_{2}$-induced antioxidant enzymes. Plant Physiology and Biochemistry 74, 9-15.

Maksimović M, Omanović-Mikličanin E, Badnjević A. 2019. What food do we want to eat? Is nanofood food of our future? In: Maksimović M, Omanović-Mikličanin E, Badnjević A, eds: Nanofood and Internet of Nano Things. Springer 1-8. 
Manikandan A, Sathiyabama M. 2016. Preparation of chitosan nanoparticles and its effect on detached rice leaves infected with Pyricularia grisea. International Journal of Biological Macromolecules 84, 58-61.

Marslin G, Sheeba CJ, Franklin G. 2017. Nanoparticles alter secondary metabolism in plants via ROS burst. Frontiers in Plant Science doi: 10.3389/fpls.2017.00832

Martínez-Ballesta MC, Zapata L, Chalbi N, Carvajal M. 2016. Multiwalled carbon nanotubes enter broccoli cells enhancing growth and water uptake of plants exposed to salinity. Journal of Nanobiotechnology doi: 10.1186/s 12951-016-0199-4

Mata-Pérez C, Sánchez-Calvo B, Padilla MN, Begara-Morales JC, Valderrama R, Corpas FJ, Barroso JB. 2017. Nitro-fatty acids in plant signaling: New key mediators of nitric oxide metabolism. Redox Biology 11, 554-561.

Medina-Andres R, Solano-Peralta A, Saucedo-Vázquez JP, Napsucialy-Mendivil S, Pimentel-Cabrera JA, Sosa-Torres ME, Dubrovsky JG, Lira-Ruan V. 2015. The nitric oxide production in the moss Physcomitrella patens is mediated by nitrate reductase. PLoS ONE doi: 10.1371/journal.pone.0119400

Molnár Á, Papp M, Kovács DZ, et al. 2020a. Nitro-oxidative signalling induced by chemically synthetized zinc oxide nanoparticles ( $\mathrm{ZnO}$ NPs) in Brassica species. Chemosphere 251, 126419, in press

Molnár Á, Rónavári A, Bélteky P, et al. 2020b. ZnO nanoparticles induce cell wall remodelling and modify ROS/RNS signalling in roots of Brassica seedlings. Ecotoxicology and Environmental Safety 206, 111158, in press

Mondal A, Basu R, Das S, Nandy P 2011. Beneficial role of carbon nanotubes on mustard plant growth: an agricultural prospect. Journal of Nanoparticle Research doi: 10.1007/s11051-011-0406-Z

Mur LA, Mandon J, Persijn S, et al. 2013. Nitric oxide in plants: an assessment of the current state of knowledge. AoB Plants doi: 10.1093/aobpla/pls052

Oliveira HC, Gomes BCR, Pelegrino MT, Seabra AB. 2016. Nitric oxide-releasing chitosan nanoparticles alleviate the effects of salt stress in maize plants. Nitric Oxide 61, 10-19.

Perazzolli M, Dominici P, Romero-Puertas MC, Zago E, Zeier J, Sonoda M, Delledonne M. 2004. Arabidopsis nonsymbiotic hemoglobin AHb1 modulates nitric oxide bioactivity. The Plant Cell 16, 2785-2794. 
Pereira AES, Narciso AM, Seabra AB, Fraceto LF. 2015. Evaluation of the effects of nitric oxide-releasing nanoparticles on plants. Journal of Physics: Conference Series 617: 012025 doi: 10.1088/1742-6596/617/1/012025

Petřivalský M, Luhová L. 2020. Nitrated nucleotides: new players in signaling pathways of reactive nitrogen and oxygen species in plants. Frontiers in Plant Science doi: $10.3389 /$ fpls.2020.00598

Pérez-de-Luque A. 2017. Interaction of nanomaterials with plants: what do we need for real applications in agriculture? Frontiers in Environmental Sciences doi: 10.3389/fenvs.2017.00012

Poborilova Z, Opatrilova R, Babula P. 2013. Toxicity of aluminium oxide nanoparticles demonstrated using a BY-2 plant cell suspension culture model. Environmental and Experimental Botany 91, 1-11.

Rümer S, Gupta KJ, Kaiser WM. 2009. Oxidation of hydroxylamines to NO by plant cells. Plant Signaling \& Behavior 4, 853-855.

Ruttkay-Nedecky B, Krystofova O, Nejdl L, Adam V. 2017. Nanoparticles based on essential metals and their phytotoxicity. Journal of Nanobiotechnology doi: 10.1186/s12951-017-0268-3

Saharan V, Sharma G, Yadav M, Choudhary MK, Sharma SS, Pal A, Raliya R, Biswas P. 2015. Synthesis and in vitro antifungal efficacy of $\mathrm{Cu}$-chitosan nanoparticles against pathogenic fungi of tomato. International Journal of Biological Macromolecules 75, 346-353.

Saifuddin N, Raziah AZ, Junizah AR. 2012. Carbon nanotubes: a review on structure and their interaction with proteins. Journal of Chemistry doi: 10.1155/2013/676815

Sanz-Luque E, Ocaña-Calahorro F, Llamas A, Galvan A, Fernandez E. 2013. Nitric oxide controls nitrate and ammonium assimilation in Chlamydomonas reinhardtii. Journal of Experimental Botany 64, 3373-3383.

Saquib Q, Faisal M, Alatar AA, et al. 2016. Genotoxicity of ferric oxide nanoparticles in Raphanus sativus: Deciphering the role of signaling factors, oxidative stress and cell death. Journal of Environmental Sciences 47, 49-62.

Sarangdevot K, Sonigara BS. 2015. The wondrous world of carbon nanotubes: Structure, synthesis, properties and applications. Journal of Chemical and Pharmaceutical Research 7, 916-933. 
Sathiyabama M, Parthasarathy R. 2016. Biological preparation of chitosan nanoparticles and its in vitro antifungal efficacy against some phytopathogenic fungi. Carbohydrate Polymers 151, 321-325.

Schwab F, Zhai G, Kern M, Turner A, Schnoor JL, Wiesner MR. 2016. Barriers, pathways and processes for uptake, translocation and accumulation of nanomaterials in plants - Critical review. Nanotoxicology 10, 257-278.

Shang Y, Hasan MK, Ahammed GJ, Li M, Yin H, Zhou J. 2019. Applications of nanotechnology in plant growth and crop protection: a review. Molecules doi: $10.3390 /$ molecules 24142558

Siddaiah CN, Veerappa K, Prasanth H, et al. 2018. Chitosan nanoparticles having higher degree of acetylation induce resistance against pearl millet downy mildew through nitric oxide generation. Scientific Reports doi: 10.1038/s41598-017-19016-Z

Silveira NM, Seabra AB, Marcos FCC, Pelegrino MT, Machado EC, Ribeiro FV. 2019. Encapsulation of S-nitrosoglutathione into chitosan nanoparticles improves drought tolerance of sugarcane plants. Nitric Oxide 84, 38-44.

Singh A, Singh NB, Afzal S, Singh T Hussain I. 2018. Zinc oxide nanoparticles: a review of their biological synthesis, antimicrobial activity, uptake, translocation and biotransformation in plants. Journal of Materials Science 53, 185-201.

Sinha N, Yeow JW. 2005. Carbon nanotubes for biomedical applications. IEEE Transactions on Nanobioscience 4, 180-195.

Sinha N, Ma J, Yeow JT 2006. Carbon nanotube-based sensors. Journal of Nanoscience and Nanotechnology 6, 573-590.

Skelly MJ, Malik SI, Le Bihan T, Bo Y, Jiang J, Spoel SH, Loake GJ. 2019. A role for Snitrosylation of the SUMO-conjugating enzyme SCE1 in plant immunity. Proceedings of the National Academy of Sciences of the United States of America 116, 1709017095.

Stamler JS, Lamas S, Fang FC. 2001. Nitrosylation: the prototypic redox-based signaling mechanism. Cell, 106, 675-683.

Stöhr C, Strube F, Marx G, Ullrich WR, Rockel P. 2001. A plasma membrane-bound enzyme of tobacco roots catalyses the formation of nitric oxide from nitrite. Planta $212,835-841$.

Stoimenova M, Igamberdiev AU, Gupta KJ, Hill RD. 2007. Nitrite-driven anaerobic ATP synthesis in barley and rice root mitochondria. Planta 226, 465-474. 
Sturikova H, Krystofova O, Huska D, Adam V. 2018. Zinc, zinc nanoparticles and plants. Journal of Hazardous Materials 349, 101-110.

Terrón-Camero LC, Peláez-Vico MÁ, Del-Val C, Sandalio LM, Romero-Puertas MC. 2019. Role of nitric oxide in plant responses to heavy metal stress: Exogenous application versus endogenous production. Journal of Experimental Botany 70, 44774488.

Tiwari DK, Dasgupta-Schubert N, Villaseñor Cendejas LM, Villegas J, Carreto Montoya L, Borjas García SE. 2014. Interfacing carbon nanotubes (CNT) with plants: enhancement of growth, water and ionic nutrient uptake in maize (Zea mays) and implications for nanoagriculture. Applied Nanoscience 4, 577-591.

Trapet P, Kulik A, Lamotte O, Jeandroz S, Bourque S, Nicolas-Francès V, Rosnoblet C, Besson-Bard A, Wendehenne D (2015) NO signaling in plant immunity: A tale of messengers. Phytochemistry Volume 112, Pages 72-79

Tripathi DK, Mishra RK, Singh S. 2017a. Nitric oxide ameliorates zinc oxide nanoparticles phytotoxicity in wheat seedlings: implication of the ascorbate-glutathione cycle. Frontiers in Plant Science doi: 10.3389/fpls.2017.00001

Tripathi DK, Singh S, Singh S. 2017b. Nitric oxide alleviates silver nanoparticles (AgNps)induced phytotoxicity in Pisum sativum seedlings. Plant Physiology and Biochemistry $110,167-177$.

Vollár M, Feigl G, Oláh D, Horváth A, Molnár Á, Kúsz N, Ördög A, Csupor D, Kolbert Zs. 2020. Nitro-oleic acid in seeds and differently developed seedlings of Brassica napus L. Plants (Basel) doi: 10.3390/plants9030406

Wang X, Han H, Liu X, Gu X, Chen K, Lu D. 2012. Multi-walled carbon nanotubes can enhance root elongation of wheat (Triticum aestivum) plants. Journal of Nanoparticle Research doi: 10.1007/s11051-012-0841-5

Wang YQ, Feechan A, Yun BW. et al. 2009. S-nitrosylation of AtSABP3 antagonizes the expression of plant immunity. Journal of Biological Chemistry 284, 2131-2137.

Wimalasekera R, Villar C, Begum T, Scherer GF 2011. COPPER AMINE OXIDASE1 (CuAO1) of Arabidopsis thaliana contributes to abscisic acid-and polyamine-induced nitric oxide biosynthesis and abscisic acid signal transduction. Molecular Plant 4, 663-678. 
Xu Y, Ren H, Liu J, Wang Y, Meng Z, He Z, Miao W, Chen G, Li X. 2019. A switchable NO-releasing nanomedicine for enhanced cancer therapy and inhibition of metastasis. Nanoscale 11, 5474-5488.

Yun B-W, Feechan A, Yin M, et al. 2011. S-nitrosylation of NADPH oxidase regulates cell death in plant immunity. Nature 478, 264-268.

Zhao G, Zhao Y, Lou W, et al. 2019. Nitrate reductase-dependent nitric oxide is crucial for multi-walled carbon nanotube-induced plant tolerance against salinity. Nanoscale 11, 10511-10523

Zhou X, Zhang J, Feng G, Shen J, Kong D, Zhao Q. 2016. Nitric oxide-releasing biomaterials for biomedical applications. Current Medicinal Chemistry 23, 25792601. 
Table 1 Nanomaterial-induced NO production in different experimental systems. Abbreviations: CNP, chitosan nanoparticle; MWCNT, multiwalled carbon nanotube; $\mathrm{ZnO} \mathrm{NPs}$, zinc-oxide nanoparticles; $\mathrm{Co}_{3} \mathrm{O}_{4}$ NPs, cobalt oxide nanoparticles; $\mathrm{Fe}_{2} \mathrm{O}_{3} \mathrm{NPs}$, ferric oxide nanoparticles.

\begin{tabular}{|c|c|c|c|c|}
\hline $\begin{array}{l}\text { Type } \\
\text { of NP }\end{array}$ & $\begin{array}{l}\text { Character- } \\
\text { istics of } \\
\text { NP } \\
\text { (average } \\
\text { diameter, } \\
\text { length, } \\
\text { form) }\end{array}$ & $\begin{array}{l}\text { Plant treatment } \\
\text { conditions }\end{array}$ & Plant species & Reference \\
\hline CNP & $\begin{array}{l}\sim 90 \mathrm{~nm} \text {, } \\
\text { spherical }\end{array}$ & $\begin{array}{l}0.01 \% \text { for } 24 \mathrm{~h} \text { via } \\
\text { excised leaves } \\
20 \mathrm{mg} / \mathrm{L} \text { for } 5 \text { davs via }\end{array}$ & $\begin{array}{l}\text { tea } \\
\text { (Camellia sinensis }\end{array}$ & $\begin{array}{l}\text { Chandra } \\
\text { et al. } 2017\end{array}$ \\
\hline \multirow[t]{3}{*}{$\begin{array}{l}\text { MWC } \\
\text { NT }\end{array}$} & $\begin{array}{l}6-12 \mathrm{~nm} \\
1-9 \mu \mathrm{m}\end{array}$ & $\begin{array}{l}\text { agar-solidified MS } \\
\text { medium }\end{array}$ & $\begin{array}{l}\text { rapeseed (Brassica } \\
\text { napus) seedlings }\end{array}$ & $\begin{array}{l}\text { Zhao et al. } \\
2019\end{array}$ \\
\hline & & & $\begin{array}{l}\text { thale cress (Arabidopsis } \\
\text { thaliana) seedlings }\end{array}$ & \\
\hline & & $\begin{array}{l}5 \mathrm{mg} / \mathrm{mL} \text { for } 24 \text { hours by } \\
\text { incubating the seedlings } \\
\text { in treatment solutions }\end{array}$ & $\begin{array}{l}\text { tomato (Solanum } \\
\text { lycopersicum) seedlings }\end{array}$ & $\begin{array}{l}\text { Cao et al. } \\
2020\end{array}$ \\
\hline $\begin{array}{l}\mathrm{ZnO} \\
\mathrm{NPs}\end{array}$ & $\sim 30 \mathrm{~nm}$ & $\begin{array}{l}250 \mathrm{mg} / \mathrm{L} \text { for } 3 \text { days via } \\
\text { nutrient solution }\end{array}$ & $\begin{array}{l}\text { rice (Oryza sativa) } \\
\text { seedlings }\end{array}$ & $\begin{array}{l}\text { Chen et al. } \\
2015\end{array}$ \\
\hline $\begin{array}{l}\mathrm{ZnO} \\
\mathrm{NPs}\end{array}$ & $\begin{array}{l}\sim 8 \mathrm{~nm}, \\
\text { spherical }\end{array}$ & $\begin{array}{l}\text { presence of } 25 \text { or } 100 \\
\mathrm{mg} / \mathrm{L} \\
2 \text { hours-long seed }\end{array}$ & $\begin{array}{l}\text { Indian mustard (Brassica } \\
\text { juncea) root } \\
\text { eggplant (Solanum }\end{array}$ & $\begin{array}{l}\text { Molnár et } \\
\text { al. } 2020\end{array}$ \\
\hline $\begin{array}{l}\mathrm{Co}_{3} \mathrm{O} \\
{ }_{4} \mathrm{NPs}\end{array}$ & $\begin{array}{l}\sim 21 \mathrm{~nm}, \\
\text { polyhedral }\end{array}$ & $\begin{array}{l}\mathrm{mg} / \mathrm{mL} \\
\text { treatment, } 0.25,0.5 \text { or } 1\end{array}$ & $\begin{array}{l}\text { melongena) root } \\
\text { protoplasts }\end{array}$ & $\begin{array}{l}\text { Faisal et } \\
\text { al. } 2016\end{array}$ \\
\hline $\begin{array}{l}\mathrm{Fe}_{2} \mathrm{O} \\
{ }_{3} \mathrm{NPs}\end{array}$ & $\begin{array}{l}\sim 22-26 \mathrm{~nm} \text {, } \\
\text { polyhedral }\end{array}$ & $\begin{array}{l}2 \text { hours-long seed } \\
\text { treatment, } 0.5 \text { or } 1 \mathrm{mg} / \mathrm{L}\end{array}$ & $\begin{array}{l}\text { radish (Raphanus } \\
\text { sativus) }\end{array}$ & $\begin{array}{l}\text { Saquib et } \\
\text { al. } 2016\end{array}$ \\
\hline $\begin{array}{l}\mathrm{Al}_{2} \mathrm{O}_{3} \\
\mathrm{NPs}\end{array}$ & $\sim 5 \mu \mathrm{m}$ & $\begin{array}{l}10,20,50100 \mu \mathrm{g} / \mathrm{mL} \text { for } \\
96 \text { hours }\end{array}$ & $\begin{array}{l}\text { tobacco (Nicotiana } \\
\text { tabacum) BY2 cell } \\
\text { suspension }\end{array}$ & $\begin{array}{l}\text { Poborilova } \\
\text { et al. } 2013\end{array}$ \\
\hline
\end{tabular}


Table 2 Ameliorating effects of exogenous chemical NO donors applied alone or in combination with nanoparticles on stresses. Abbreviations: MWCNTs, multiwalled carbon nanotubes; SNP, sodium nitroprusside; TiO2 NPs, titanium dioxide nanoparticles; ZnO NPs, zinc oxide nanoparticles; SOD, superoxide dismutase; CAT, catalase; APX, ascorbate peroxidase; LPO, lipid peroxidation; $\mathrm{H}_{2} \mathrm{O}_{2}$, hydrogen peroxide; ROS, reactive oxygen species; AsA, ascorbate; $\mathrm{GSH}$, glutathione; POX, peroxidase; GR, glutathione reductase; DHAR, dehydroascorbate reductase; Ag NPs, silver nanoparticles.

\begin{tabular}{|c|c|c|c|c|}
\hline $\begin{array}{l}\text { Stress } \\
\text { ameliorating }\end{array}$ & Stressor & Plant species & Effects & Reference \\
\hline $\begin{array}{l}\text { MWCNTs } \\
(500,1000, \\
2000 \mathrm{mg} / \mathrm{kg}) \\
+ \text { SNP }(100 \\
\mu \mathrm{M})\end{array}$ & $\begin{array}{l}100 \text { or } \\
200 \mathrm{mM} \\
\mathrm{NaCl}\end{array}$ & $\begin{array}{l}\text { barley } \\
\text { (Hordeum vulgare) }\end{array}$ & $\begin{array}{l}\text { improved } \\
\text { photosynthesis, } \\
\text { chlorophyll } \\
\text { content, relative } \\
\text { water content, } \\
\text { increased SOD, } \\
\text { CAT, APX, } \\
\text { proline content, } \\
\text { reduced LPO, } \\
\mathrm{H}_{2} \mathrm{O}_{2}\end{array}$ & $\begin{array}{l}\text { Karami and Sepehri } \\
2018 a\end{array}$ \\
\hline $\begin{array}{l}\mathrm{TiO}_{2} \mathrm{NPs} \\
(500,1000, \\
2000 \mathrm{mg} / \mathrm{kg}) \\
+ \text { SNP }(100 \\
\text { uM) }\end{array}$ & $\begin{array}{l}100 \text { or } \\
200 \mathrm{mM} \\
\mathrm{NaCl}\end{array}$ & $\begin{array}{l}\text { barley } \\
\text { (Hordeum vulgare) }\end{array}$ & $\begin{array}{l}\text { increased SOD, } \\
\text { CAT, APX, } \\
\text { reduced LPO, } \\
\mathrm{H}_{2} \mathrm{O}_{2}\end{array}$ & $\begin{array}{l}\text { Karami and Sepehri } \\
2018 b\end{array}$ \\
\hline $\begin{array}{l}\mathrm{TiO}_{2} \mathrm{NPs} \\
(50,1000, \\
2000 \mathrm{mg} / \mathrm{L}) \\
+\mathrm{SNP}(100 \\
\mu \mathrm{M})\end{array}$ & $\begin{array}{l}50 \text { or } \\
100 \mathrm{mM} \\
\mathrm{CdCl}_{2}\end{array}$ & $\begin{array}{l}\text { wheat } \\
\text { (Triticum aestivum) }\end{array}$ & $\begin{array}{l}\text { improved } \\
\text { germination and } \\
\text { biomass } \\
\text { production }\end{array}$ & Faraji et al. 2018 \\
\hline $\begin{array}{l}\mathrm{TiO}_{2} \mathrm{NPs} \\
(2000 \mathrm{mg} / \mathrm{kg}) \\
+\mathrm{SNP}(100 \\
\mu \mathrm{M})\end{array}$ & $\begin{array}{l}\text { drought } \\
\text { by } \\
\text { limited } \\
\text { water }\end{array}$ & $\begin{array}{l}\text { wheat } \\
\text { (Triticum aestivum) }\end{array}$ & $\begin{array}{l}\text { improved growth, } \\
\text { photosynthesis, } \\
\text { SOD activity, } \\
\text { decreased LPO }\end{array}$ & $\begin{array}{l}\text { Faraji and Sepehri } \\
2020\end{array}$ \\
\hline & supply & & $\begin{array}{l}\text { and } \mathrm{H}_{2} \mathrm{O}_{2} \\
\text { improved growth, } \\
\text { reduced } \mathrm{Zn}\end{array}$ & \\
\hline & $\begin{array}{l}\sim 30 \mathrm{~nm} \\
\mathrm{ZnO}\end{array}$ & & $\begin{array}{l}\text { accumulation, } \\
\text { mitigated ROS }\end{array}$ & \\
\hline $10 \mu \mathrm{M}$ SNP & $\begin{array}{l}\text { NPs, } \\
250 \\
\mathrm{mg} / \mathrm{L} \text { for } \\
3 \text { days }\end{array}$ & $\begin{array}{l}\text { rice } \\
\text { (Oryza sativa) }\end{array}$ & $\begin{array}{l}\text { accumulation, } \\
\text { increased GSH, } \\
\text { SOD, POX, CAT, } \\
\text { APX enzyme } \\
\text { activities and } \\
\text { gene expression }\end{array}$ & Chen et al. 2015 \\
\hline
\end{tabular}




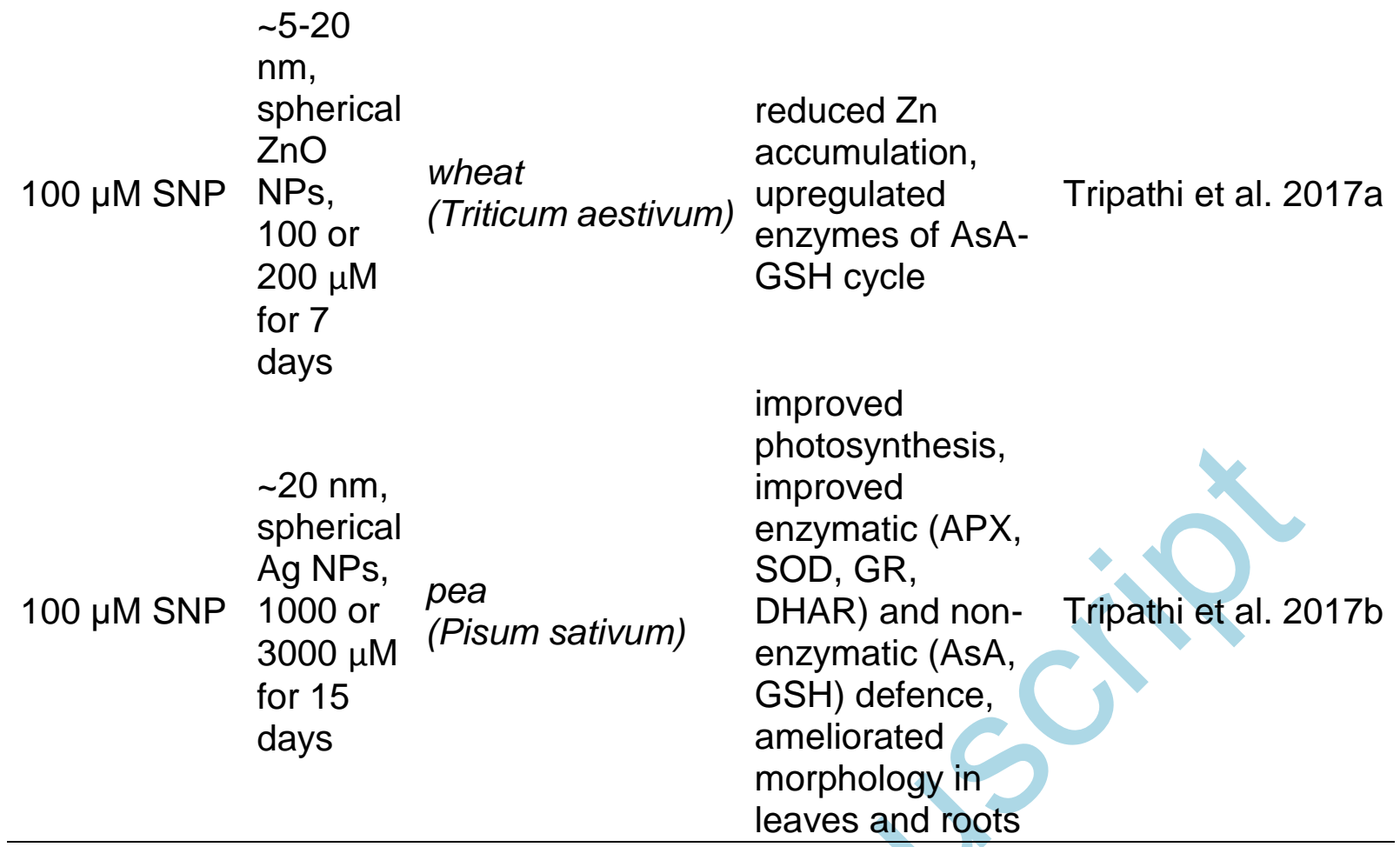


Table 3 Effects of NO-releasing nanoparticles (NO NPs) on different plant species. Abbreviations: GSNO, S-nitrosoglutathione; S-nitroso-MSA CS NP, Snitroso-mercaptosuccinic acid chitosan nanoparticles; SNO, S-nitrosothiol; GSNO CS NP, S-nitrosoglutathione chitosan nanoparticles; PEG, polyethylene glycol;

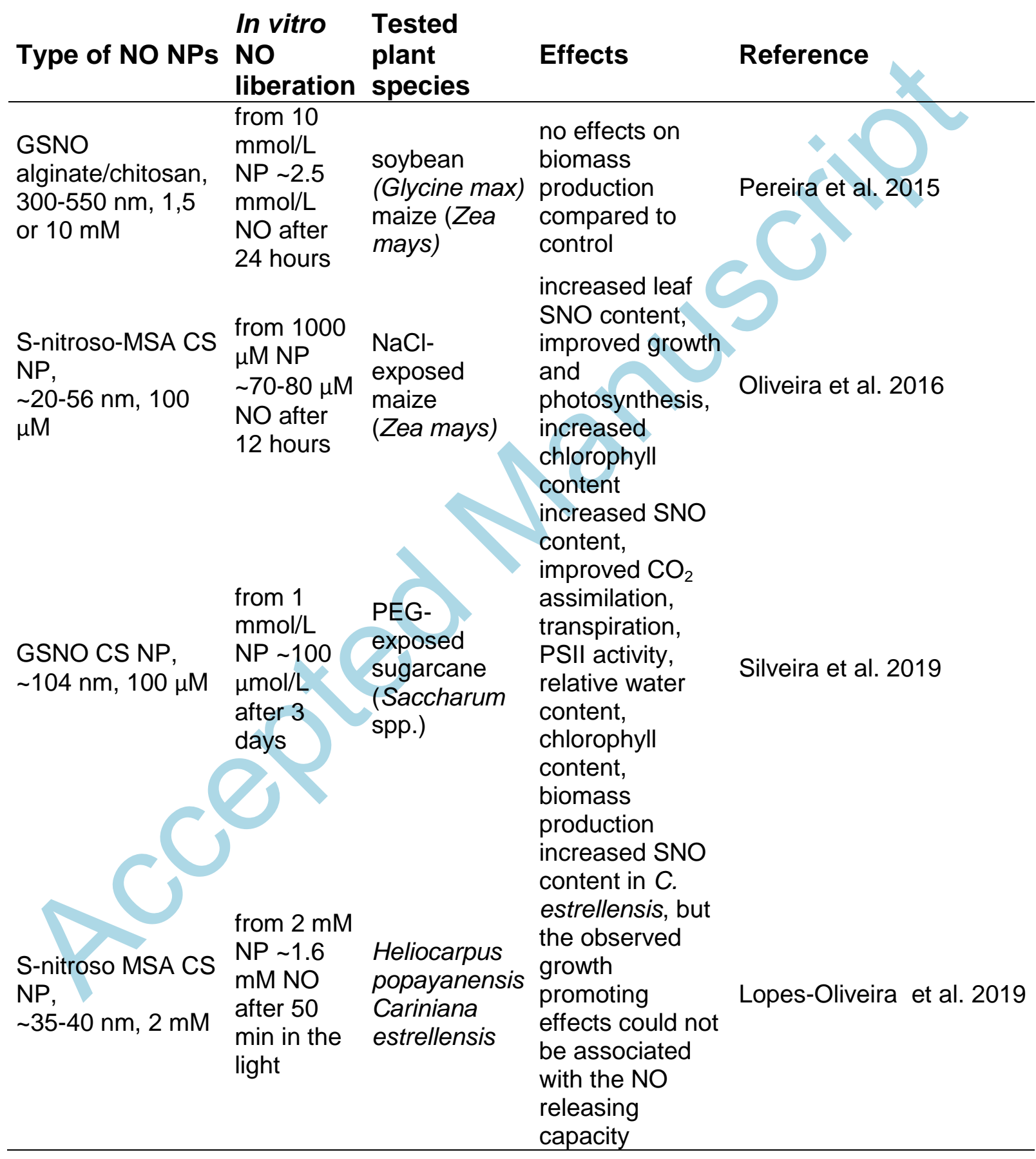




\section{Figure legends}

Figure 1. Reactions and signalling of NO in plant cells resulting in regulation of growth, development and stress responses. See explanations in the text. Scavenging reactions are indicated by grey arrows. Putative consequences are indicated by dashed arrows.

Figure 2 The effects of endogenous and exogenous NO in nanoparticle-exposed plants. Enhanced NO production due to NP (chitosan NPs, nanotubes, NO NPs) or chemical NO donor treatments exerts beneficial effects such as participating in pathogen defence, contributing to salt tolerance and promoting plant growth. On the other hand, NO accumulation in plants exposed to metal-oxide NPs contributes to toxicity via macromolecule damage (e.g. protein nitration) and cell death. 


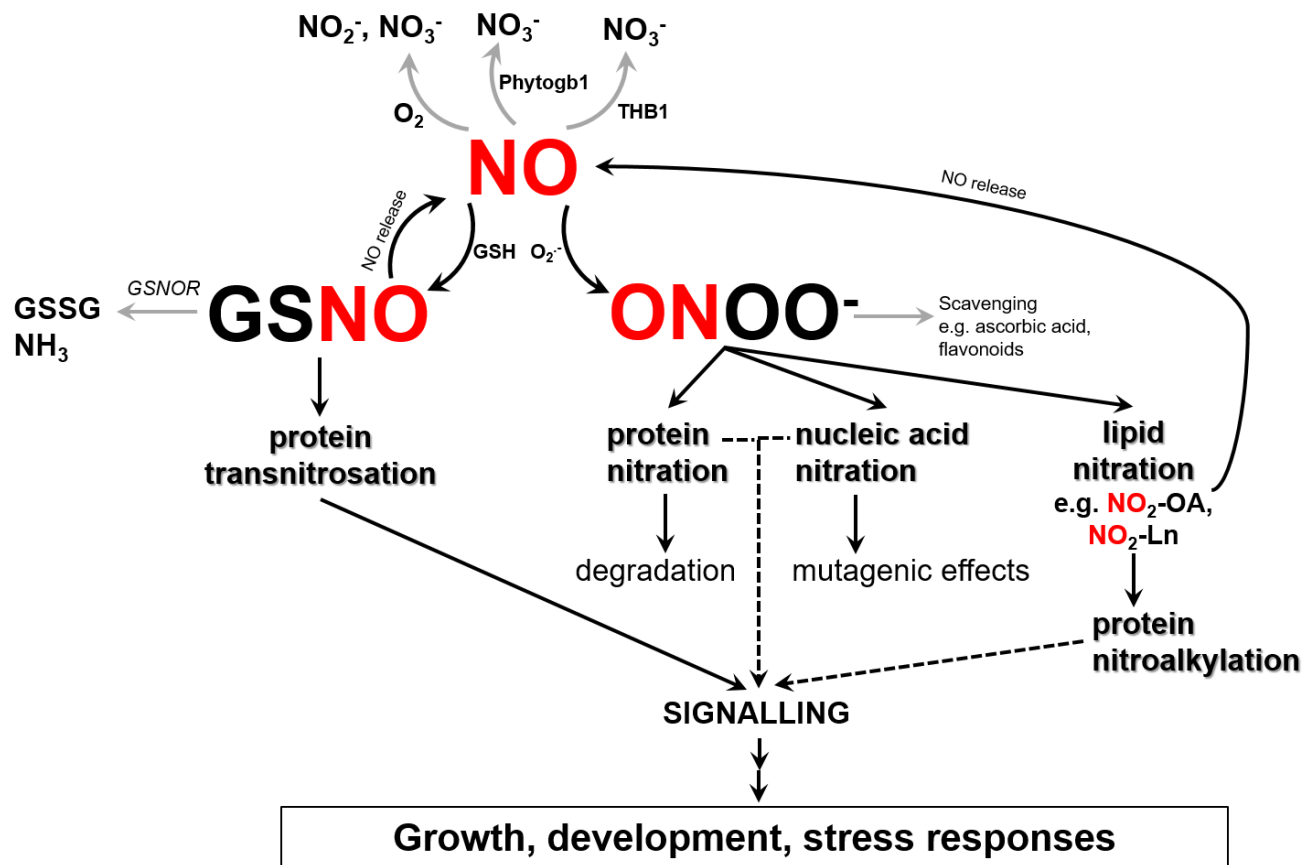


Figure 2

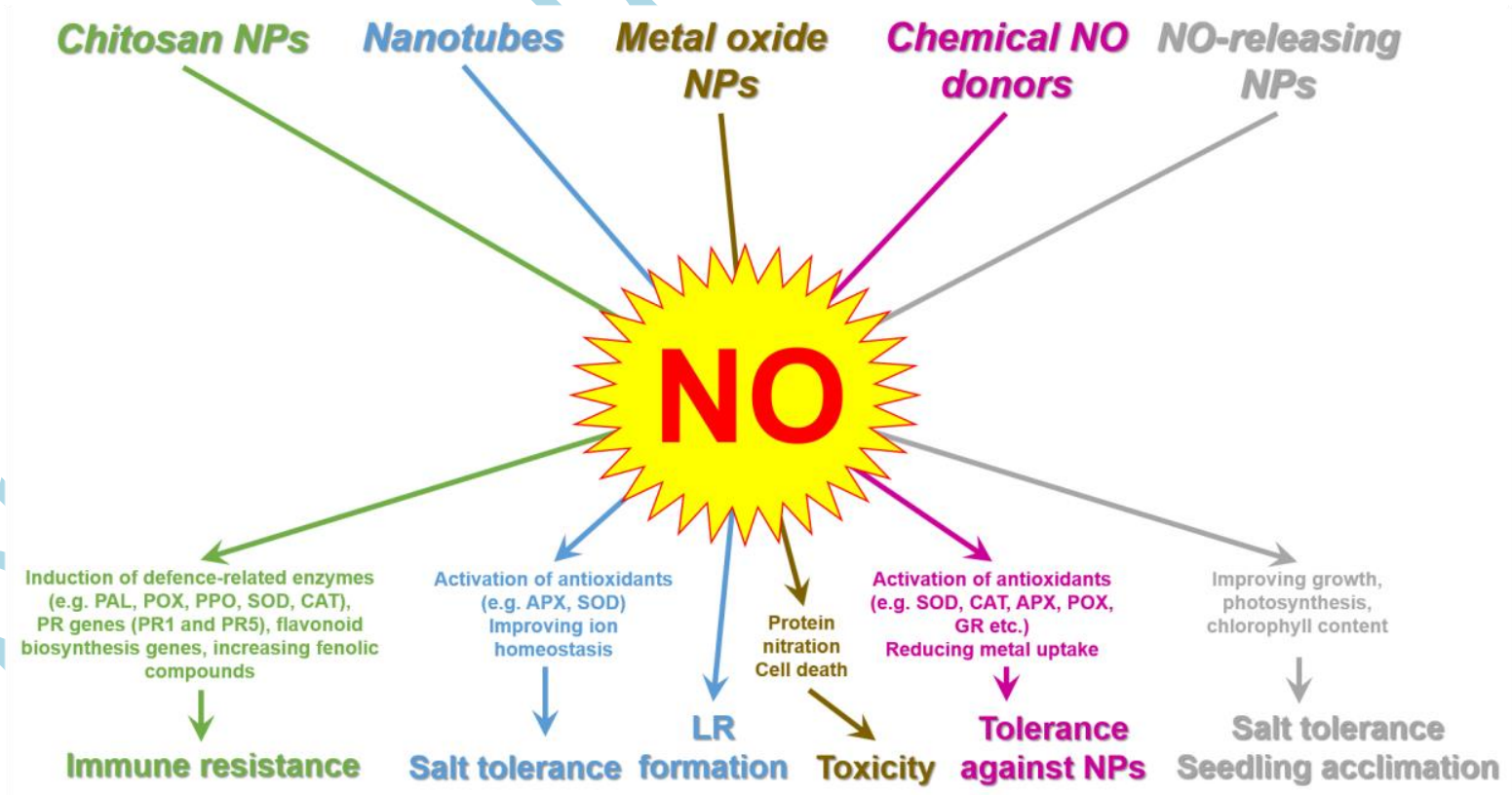

